\title{
NTRK1 Gene
}

National Cancer Institute

\section{Source}

National Cancer Institute. NTRK1 Gene. NCI Thesaurus. Code C18551.

This gene is involved in cellular differentiation and neurotrophic functions. 